\title{
Cultural awareness for intercultural communication in English language learning
}

\section{Saodatkhan KHODJAEVA ${ }^{1}$}

Uzbek State University of World Languages

\begin{tabular}{l} 
ARTICLE INFO \\
\hline Article history: \\
Received February 2021 \\
Received in revised form \\
20 February 2021 \\
Accepted 15 March 2021 \\
Available online \\
15 April 2021 \\
\hline Keywords: \\
intercultural \\
communication, \\
foreign language, \\
subject's interaction, \\
culture teaching, \\
professional qualities, \\
a highly qualified specialist.
\end{tabular}

ABSTRACT

Intercultural communicative competence plays an important role in the development of students' language and communication skills. This article examines the cultural characteristics of intercultural communication in the study of the English language. Intercultural communication is a new "borderline" subject closely related to the teaching of English in higher education institutions. Thus, the proper use of linguistic and cultural skills is an essential part of intercultural communication skills. (CC BY 4.0) license (https://creativecommons.org/licenses/by/4.0/deed.ru)

\section{Инглиз тилини ўрганишда маданиятлараро мулоқот учун маданий хабардорлик}

\section{Калит сўзлар:}

маданиятлараро мулоқот, чет тили,

субьектларнинг ўзаро

мулоқоти,

маданиятни ўқитиш, касбий фазилатлар, юқори малакали мутахассис.
АННОТАЦИЯ

Маданиятлараро коммуникатив қобилият -

талабаларнинг тил ва коммуникатив кўникмаларини ривожлантиришда мухим роль уйнайди. Ушбу мақолада инглиз тилини ўрганишда маданиятлараро мулоқотнинг маданий хусусиятларини ёритган. Маданиятлараро алоқа бу олий ўқув юртларида инглиз тилини ўқитиш билан чамбарчас боғлиқ янги «чегаравий» машғулот.

Лингвистик ва маданий кўникмалардан тўғри фойдаланиш талабаларни маданиятлараро мулоқот қобилиятларининг мухим қисмидир.

\footnotetext{
${ }^{1}$ senior lecturer, Uzbek State University of World Languages, Tashkent, Uzbekistan.
} 


\section{Культурная осведомленность для межкультурного общения при изучении английского языка}

\author{
Ключевые слова: \\ межкультурное общение, \\ иностранный язык, \\ взаимодействие субъектов, \\ обучение культуре, \\ профессиональные \\ качества, \\ высококвалифицированный \\ специалист.
}

\section{АННОТАЦИЯ}

Межкультурная коммуникативная компетенция играет важную роль для развития языковых и коммуникативных способностей студентов. В данной статье рассматриваются культурные особенности межкультурного общения при изучении английского языка. Межкультурное общение это новый «пограничный» предмет, тесно связанный с преподаванием английского языка в Высших образовательных учреждениях.

Таким образом, надлежащее использование языковых и культурных навыков является важнейшей частью межкультурных коммуникативных умений.

Language is a gift that expands a person's abilities, thinking, perception, memory and imagination. We think in the language we speak and each language reflects the same reality in its own way. Therefore, it must be precise so that we can understand each other; it must be flexible in order to allow words to take on new shades of meaning. Many foreigners speak several languages, while in our country few know at least one foreign language and have no idea what advantages and opportunities it gives [1].

To learn a foreign language, you have to master the knowledge, skills and have to understand the language, which reflected the foreign culture, to overcome cultural barriers, communicate with foreigners decently and effectively and have emotional communication and cross-cultural communication.

As the university English teachers in the new era, we should undertake the new mission, combine the language teaching with culture teaching, and develop students' intercultural communicative competence.

Mastering a foreign language, we expand our horizon of knowledge, plunge into another linguistic universe, enrich vocabulary, develop memory, and improve mental abilities. This leads to better integration into the foreign and linguistic environment and the earliest adaptation to its conditions [2]. The task of the higher school is to create conditions for the formation and development of the student's professional qualities. Specially created components of the educational process and a purposefully organized space for the formation of professional competencies contribute to the development of a student's need for joint activities, development of an interaction strategy, mastery of certain knowledge, skills and abilities [3].

The article deals with the relationship between special subjects and a foreign language, identifies new approaches to teaching a foreign language, considers the requirements for a specialist in a technical university, and outlines the need to prepare for professional activities in the field of teaching a foreign language. The relationship between teaching foreign languages and intercultural communication is obvious. In the field of studying foreign languages, great changes are taking place, which are caused by a great interest in it. The unprecedented demand generated the need for a corresponding supply. Specialists from various fields demanded immediate training in foreign languages as a tool of production and as a means of real communication with people from other countries. 
New time dictates the tendency of immediate revision of the general methodology and techniques of teaching foreign languages [4]. In a higher educational institution, teaching a foreign language as a means of communication between specialists from different countries is not considered as an applied and highly specialized task. A university specialist is an educated person with fundamental training. The foreign language of such a specialist is both an instrument of production and a part of culture. To teach a foreign language, it is necessary to create an environment of real communication: to arrange scientific discussions in a foreign language with the involvement of specialists, to use special vocabulary and terminology in the classroom, to participate in international conferences. Development of communication skills is the main task facing teachers of foreign languages [5]. The development of modern production is impossible without foreign experience: a specialist of the direction of intercultural communication of linguistic provision must be prepared for international interaction and cooperation, both at the linguistic and professional level. On the one hand, a specialist is enriched with a baggage of knowledge and experience in the field of his professional activity, on the other hand, he / she must be able to establish contacts and transfer the accumulated experience and achievements of his/ her country through intercultural communication. A highly qualified specialist should not be limited only to knowledge of the language; his / her main task is to obtain a specific result in professional activity through the use of the language. Therefore, the main goal of international communication and contacts in the learning process is to prepare the future professional to use the knowledge and skills acquired, aimed at developing the economy and production of the country's region [6].

For example:

$>$ The classroom teaching is the important position of cultivating students' intercultural awareness, and therefore the most important thing is to train the students' intercultural awareness and ability in the classroom;

$>$ Take the culture as teaching objectives and content, set phases goals, this goal is clear and it is convenient for teacher to operate;

$>$ strengthen the cultural background information introduction, let the students learn language and understand the culture from different angles;

$>$ By using a visual media experience foreign culture in different ways, teachers may find information and use multimedia, let the students not only understand western culture but also through actual context to learn how to use the language by social application;

$>$ Pay attention to cultural differences, strengthen cultural comparison, raise cultural awareness, make good culture knowledge introduction, and enhance students' sensitivity to cultural differences. It is also a higher demand for teachers to cultivate intercultural communicative awareness and competence, teachers must spend a lot of time to find the corresponding teaching materials and teaching methods.

The solution of educational problems is widely associated with education in the direction of intercultural communication of linguistic provision, but it can be successfully applied in the study of a foreign language, especially when this process takes place in mastering a dual competence: the study of a foreign language and the simultaneous assimilation of expert knowledge in technical fields. Productive educational and professional activity in the study of a foreign language takes place in conditions of co-creation, when the student's individual creative work is combined with the creativity of other subjects of this activity, which in no way diminishes the importance of the individual 
creative style. On the contrary, it teaches students to bring the best examples of collective creativity into their individual experience and allows them to hone, improve their professional style and achieve high results in creativity [7].

We study intercultural communication not only focus on the definition of culture and characteristics, the definition of communication as well as the relationship between culture and communication, we should focused on the cultural factors which interfere communication. Through the above analysis and research, we can clearly recognize, intercultural communicative competence is just like a bridge, combine the language ability with communicative ability. Intercultural communicative competence plays a vital role for the cultivation of language and communication ability, intercultural communication is a new "edge" subject, which has a close relationship with English teaching. As the university English teachers in the new era, we should undertake the new mission, combine the language teaching with culture teaching, develop students lintercultural communicative competence, enable students to become all-round developed students. The creation of a linguistic para-environment in the educational process is a decisive condition for the formation of communicative competence. The audiovisual linguistic environment contributes to the creation of conditions for the assimilation of the language in contact with the culture, which is modeled in this para-environment. You can also use the Internet as an accessible means of teaching and learning, obtaining information, communication. The correct use of computer telecommunications, information resources and Internet services will allow for a fundamentally new approach to learning, which:

- is based on broad communication, rapprochement, blurring the boundaries between individual societies, on the free exchange of opinions and information;

- initiates wide contacts with the culture of other peoples and their experience.

- stimulates the acquisition of a foreign language when it comes to international projects [8]. In connection with the development of countries, the need for knowledge of a foreign language to lead an intercultural community to understand communicants belonging to different ethnic cultures within their country or abroad is significantly increasing.

\section{THE LIST OF USED LITERATURE:}

1. Foreign language and your possibilities [Electronic resource] Access mode: student45.ru/why.../foreign-language-and-oppurtunities/, free.

2. Z.S. Sergeeva. Bulletin of Kazan Technological University, 14, 16, 300-302 (2011).

3. S. A. Murtazina, G. A. Garifullina, Bulletin of Kazan Technological University, 14, 16, 309-314 (2011).

4. Ter-Minasova. [Electronic resource] Access mode: www.gumer.info/ bibliotek_Buks/Linguist /.../_ 04.php

5. M.E. Eliseeva. Intercultural communication and study of foreign languages Samara state acad. cool and art.

6. Yu.N. Ziyatdinova, E.E. Valeeva. Bulletin of Kazan Technological University, 14, 16, 292-300 (2011).

7. S.D. Pivkin, N.Sh. Valeeva. Bulletin of Kazan Technological University, 14, 16, 303-309 (2011).

8. E.S. Polat, M.Yu. Bukharkina. New pedagogical and information technologies in the education system: Textbook - M.: Publishing Center "Academy", 2008.

9. Liu Aizhen. The cultural understanding and propriety of language. Language, 2000. 